\title{
LOCAL PERSPECTIVES OVER CULTURAL TOURISM TO HERITAGE SITES. THE CASE STUDY OF ORADEA FORTRESS (ROMANIA)
}

\author{
Cezar MORAR* \\ University of Oradea, Department of Geography, Tourism and Territorial Planning, 1 University Street, Oradea 410087, Romania, e-mail: cezar.morar@gmail.com \\ Vasile GRAMA \\ University of Oradea, Department of Geography, Tourism and Territorial Planning, 1 University Street, Oradea 410087, Romania, e-mail: vasile.grama2014@gmail.com
}

Marius I. STUPARIU

University of Oradea, Department of Geography, Tourism and Territorial Planning, 1 University Street, Oradea 410087, Romania, e-mail: marius_stupariu@yahoo.co.uk

\section{Gyula NAGY}

University of Szeged, Department of Economic and Social Geography, 2 Egyetem Street, Szeged 6722, Hungary, e-mail: geo.nagy.gyula@ gmail.com

\section{Lajos BOROS}

University of Szeged, Department of Economic and Social Geography, 2 Egyetem Street, Szeged 6722, Hungary, e-mail: borosl@geo.u-szeged.hu

\section{Alexandru TIBA}

University of Oradea, Department of Psychology, 1 University Street, Oradea 410087, Romania, e-mail: alexandrutiba@ gmail.com

\section{Maria GOZNER}

University of Oradea, Department of Geography, Tourism and Territorial Planning, 1 University Street, Oradea 410087, Romania, e-mail: mariagozner@yahoo.com

\author{
Mariana SZABO-ALEXI
}

University of Oradea, Department of Physical Education, Sports and Physical Therapy, 1 University Street, Oradea 410087, Romania, e-mail: mariszabo@yahoo.com

Citation: Morar, C., Grama, V., Stupariu, I.M., Nagy, G., Boros, L., Tiba, Al., Gozner, M., \& Szabo-Alexi, S. (2020). LOCAL PERSPECTIVES OVER CULTURAL TOURISM TO HERITAGE SITES. THE CASE STUDY OF ORADEA FORTRESS (ROMANIA). GeoJournal of Tourism and Geosites, 33(4spl), 1470-1479. https://doi.org/10.30892/gtg.334spl04-595

\begin{abstract}
The Fortress of Oradea is one the most representative in Transylvania, which strongly influenced the socio-economic development of the city, in the same time turning the settlement into a cultural and multiethnic center, with impacts on the architecture of the city. The main aim of the paper is to explain the importance of the cultural, historical, architectural values of the fortress from a local perspective. The que stionnaire sampling method was used in the present study, further interpreting the questionnaire, the results underlining the historical significance and authenticity were generated. These issues generate functions, justifies the dominating role in the urban texture of Oradea, requiring in the same time integrative planning and special policy measures for the heritage protection, in an overall sustainable development context.
\end{abstract}

Key words: cultural heritage, medieval fortress, tourism, sustainability, Oradea, Romania

\section{INTRODUCTION}

The space is interrelated with the existence of the population that inhabits it, conditioning not only the physical limits of the expansion of a community but also its mental attitude towards the surrounding world (Soja, 1989; Lefebvre, 1991). The concepts of mental, cognitive and living space (l'espace vecu) were later developed, which designate spaces which are well individualized over time based on traditions, economic-social complementarities and common cultural and social heritage through the process of epistemology, cognition and experiencing of spaces (Downs and Stea, 1973; Ennen, 2000; Ashworth et al., 2007; Bohland and Hauge, 2009; Niemets et al., 2018). The functionality of space is influenced by the behavior, the mentality of the inhabitants, and reflects the identity of the inhabitants, the communion and interactions between people and environment (Downs and Stea, 1973; Dezsi et al., 2014; Azhayev et al., 2020; Suleimenov et al., 2020). Mental and cognitive spaces are functional spaces but also spaces of ethnic, cultural homogeneity or diversity, structured from the bottom up, based on the relations between the local communities (Mugnano and Palvarini, 2013; Valentine, 2013; Ilieş et al., 2015, 2018; Gozner et al., 2017; Deac et al., 2019; Herman et al., 2019). Interactions between different groups and communities can result in clash of cultures and behaviors creating conflicts (LeBaron, 1993). Cultures and communities are always changing, and they relate to the symbolic dimension of life (LeBaron, 2003), but the interaction between them not necessarily have negative effects on the localities.

Culture can contribute to a healthier society, facilitates civic involvement and gives tourists a reason to visit. It continu es to shape the heritage and identity of cities, creates jobs and introduces pro-social behavior for young people in the community thus helps to strengthen tolerance and acceptance (Forrest and Kearns, 2001; Lugosi et al., 2010). Culture helps to address all the major challenges of cities we face today - it has definitely moved from the niche to the mainstream. Based on cultural identity and historical heritage, slowly, cities are being reshaped through their specific culture (Pap, 2014; Ropa and Ropa, 2015; Ilies et al., 2020). This strategic repositioning of culture in the city landscape did not happen by chance. It happened because of the dedication, faith and leadership of artists, organ izations and, of course, city leaders (World Cities Culture Report, 2018). This also may result the capitalization of the cultural-historical heritage for tourism purposes, and may end up in the commodification of culture (Harvey, 2002; Sheperd, 2002; Herman, 2020a). An unprecedented

\footnotetext{
${ }^{*}$ Corresponding author
} 
development started throughout the European continent in the last decades based on culture, offering local communities unique opportunities for social and economic development based on their cultural heritages (Enyedi and Kovács, 2006; Bowitz and Ibenholt, 2007; Smith et al., 2018; Morar et al., 2019). Culture-motivated tourism became the link between urban cultural capital and socioeconomic development in urban area and the elements of culture became inseparable from urban regeneration and tourism develop ment as well. The importance of culture as part of the European tourism experience is recognized as an element that can enhance the profile of Europe as a global destination thanks to an incomparable cultural heritage, that includes several elements of tangible and in tangible heritage; e.g. museums, theatres, archaeological, historical and industrial sites as well as music, gastronomy, rituals and traditions (Niemets et al., 2019). Due to their complexity, cities are among the most important places of cultural tourism in Europe. Visitor influx tends to be concentrated in urban centers, which overlap unevenly with historic centers. They are places that attract many visitors due to their relevance in terms of heritage (Ennen, 2000; García-Hernández et al., 2017). Heritage is a broad concept that has different meanings for different people. Inheritance is the reproduction of the past in the present, it is about what we value now, as a person, as a group, as a society (Ashworth, 1991; Lowenthal, 1998). Cultural and historical heritage are used to build national identity, it is used for economic benefits and to identify places, it is used to promote diversity and to promote sustainable development (Shomanova et al., 2017; Monyók et al., 2020; Lečić et al., 2017). UNESCO's policies and programs have promoted the protection of tangible and intangible heritage for decades through creative cultural industries and appealing to cultural pluralism that empowers society's tolerance of others.

New approaches focused on culture and people in the discourse of heritage see culture and cultural heritage as an asset and driving force for sustainable urban development. Discussions on this issue began to develop after 1960 and here we mention the UNESCO Convention for the Safeguarding of Intangible Cultural Heritage (2003) and the UNESCO Convention on the Diversity of Cultural Expressions (2005), introducing in the literature concepts such as heritage community and common heritage. In the new vision, the cultural heritage has a positive impact on the cities, through its contribution to the improvement of the quality of life, the social development and the strengthening of the feeling of local belonging (The Implementation of the UNESCO Historic Urban Landscape Recommendation, 2018).

Local communities aiming progress and development of city centers to live in modern, vibrant, functional cities where they can culturally develop (Rátz et al., 2015; Smith et al., 2018). While heritage culture-based tourism practice may help conserve a destination's cultural heritage, its development accelerates the change of the local society (Li, 2003). Through education and culture-led development the city's image is improved and it can boost place identity and can sell the city as commodity (Gospodini, 2006; Ropa and Ropa, 2015). Harvey thinks that cities increasingly use their cultural and built heritage to fix and to defent the meaning and value of places (Harvey 1989) but in the same commodifying them (Harvey, 2002). Kisic believes that present day conflict between capital making priorities and cultural growth can be overcome by proper governance of cultural heritage (Kisic, 2016). But for this, the cultural resources are to be assumed a function that is economically viable, so that the local communities could appreciate their values in their lives (Corten et al., 2014).

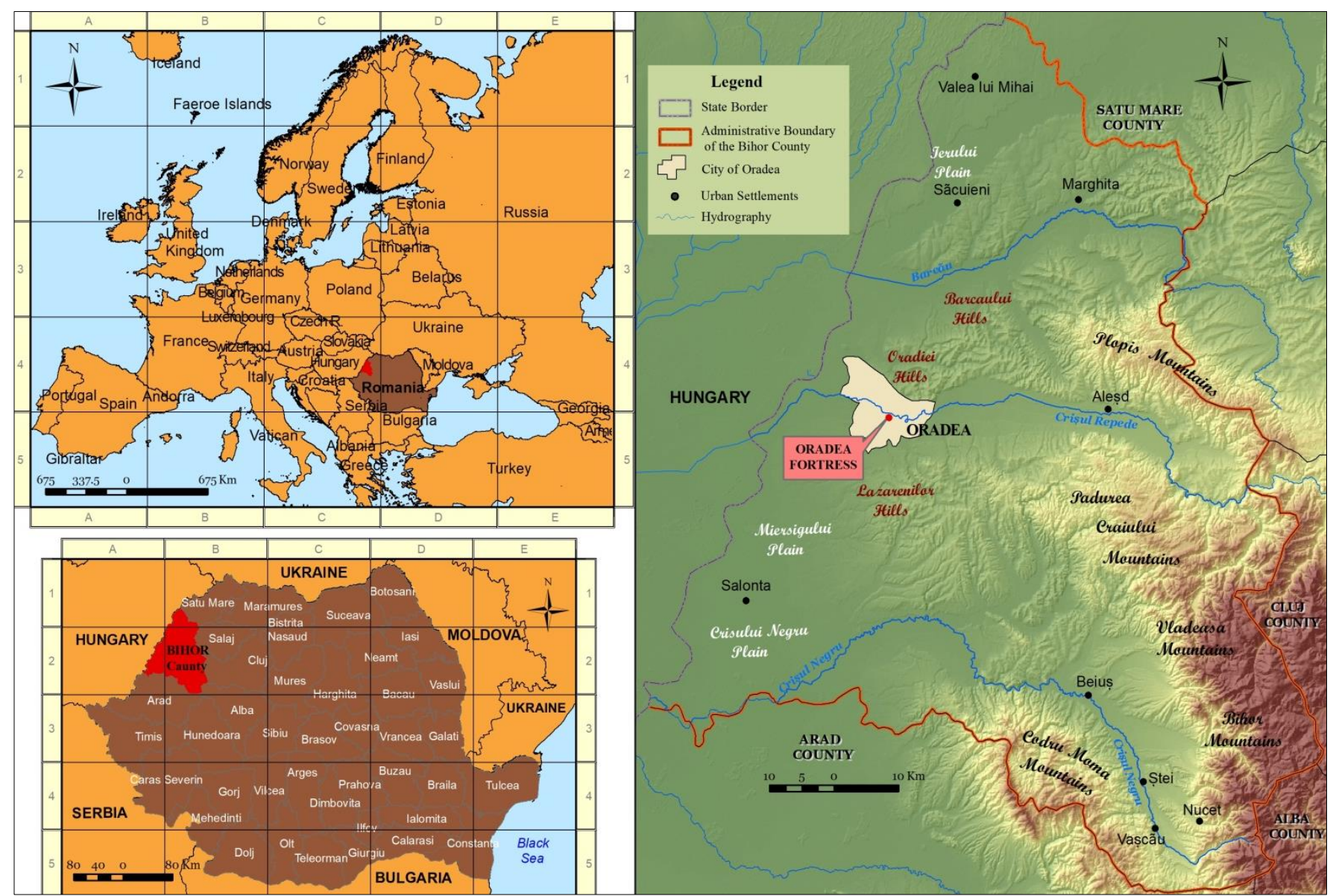

Figure 1. Localization of the study area: within Europe (top left), Romania (down left) and Bihor County (right) (data source: Ortophoto, National Romanian Agency for Cadastral Surveys and Real Estate Publicity)

Attempts to understand the processes and outcomes associated with urban heritage tourism development usually fall into one of two groupings: a "top-down" perspective stressing the role of global factors and external actors in driving urban redevelopment; and a "bottomup" perspective focusing on local influences (Chang et al., 1996; Hampton and Wellman, 2003). 
Unique cultural heritage elements may be tangible or intangible have significant effect on the urban environments and the local identity as well. The use of cultural heritage is a tool to distinct urban landscapes (Gospodini, 2006) in the urban texture. With an imposing presence in any urban landscape, urban heritage appear to work as place identity generators (Gospodini, 2004). Historical monuments play a profound role in the lives of local communities, providing an important sense of attachment and identity, connection to specific spaces through an invitation to travel to the mysterious world of the Middle Ages. As an example, a fortresse represents true testaments of history, which complete through bold architecture entire pages of local history, arousing real passions for tourists and becoming a must-see destination for any traveler. This paper analyses a special form of urban heritage and its touristic significance through its specific characteristic which have effect on the image of the city and on the mental cognitive image of tourists visiting it. Located in the west of the country, on the border with Hungary, Oradea (Romania) (fig. 1) is distinguished by a rich archaeological, historical, art and architectural heritage (Lakos, 1904; Scholtz, 1907; Firu, 1924; Dejeu, 1926, 1937,1938; Biró, 1932; Borcea, 1976; Kovács and Țoca, 1973, 1977, 1979; Balogh, 1982; Gazdag, 1982; Dudaș, 1996; Rusu, 2002; Kovács, 2003; Borcea and Gorun, 2007; Pașca, 2010 a, b; Ilieş et al., 2010; Badiali and Ilieș, 2011; Chifor, 2011; Ilies et al., 2011; Morar, 2013; Ilies et al., 2014; Badiali et al., 2018; Morar et al., 2019; Herman et al., 2020b) that attests to the evolution and permanence of these lands. All this cultural-historical background forms a significant part of the tourist offer and a component of the tourist image of the city on the regional and international market. The main aim of the paper is to underline the importance of the cultural, historical, architectural values of the fortress, from a local perspective.

\section{DATA AND METHODS}

All true historical events or with the status of legend related to these monuments represent an important source of identity, memory and sense of place, causing a feeling of spiritual attachment among the local community. They are, therefore, real landmarks from a social point of view. Often neglected, or even abandoned, these historical monuments seem to lose precisely these defining attributes, but a community that loves its history will succeed in bringing to light these values - economic, social, sentimental - through an attempt to gather - a sustainable symbiosis of people, places and history. Our research questions focus both on the material and mental aspects of heritage space. Thus we formulated two main questions. What are the characteristics of the fortress of Oradea? How the values of the fortress are perceived and interpreted? Further, this paper argues for an integrative approach trying to underline the perception of the local community towards Oradea Fortress - one of the most representative heritage elements existing in the city of Oradea. The paper explains the importance and value of the cultural heritage elements, in connection to the medieval fortress in the city of Oradea, Romania.

The questionnaire sampling method was used in the present study, with a face-to-face implementation technique. The applied sampling method was non probability sampling reliance on the available subject method with a quota on gender. Among others, the questionnaire targeted the degree of knowledge of Oradea Fortress, historical moments and people associated with the Fortress, frequency of visits, main reasons to visit, the Fortress as a venue of festivals and fairs, main values added to the Fortress by local community and different opinions related to local initiative. The necessary data to carry out the present study was obtained in the June-September 2020 time frame, in various locations from Oradea city using the method of sociological survey based on questionnaire (Chelcea, 2007; Bryman, 2012; Bar et al., 2016; Wendt et al., 2019). Structurally, the questionnaire was composed of 6 units with 14 items referring to: knowledge of Oradea Fortress, historical moments and people, frequency of visits, reasons to visit, venue of festivals and fairs, main values and local initiative. Furthermore, in the questionnaire was captured socio-demographic information relevant for tourism: gender, age, level of education, income etc. The information regarding the perception Oradea Fortress was obtained by consulting 80 people.

\section{DISCUSSION AND RESULTS}

\section{THE FORTRESS OF ORADEA, A HERITAGE SITE}

The city of Oradea (northwestern Romania) is one of the oldest fortified settlements in Transylvania, part of the Austro-Hungarian Empire (until 1918). The settlement it is first mentioned under the name Varadinum in 1113 in a diploma of the Benedictine abbey in Zobor ${ }^{1}$. The Fortress of Oradea (Figure 2) is composed of five bastions each with a different name (Bethlen Bastion, Crăişorul Bastion, Red Bastion, Gold Bastion, Ciunt Bastion), 13 buildings, two gates (Western Gate and Eastern Gate) and the Roman-Catholic Church, all presented bellow (Kovács, 1973; Kovács and Ţoca, 1977; Balogh, 1982; Emődi, 1998; Emődi, 1998; Emődi, 2007; Emődi, 2009).

In the first phase of construction of the fortification, the West Gate was the only access way in the fortress. It was design ed and built during the rule of Prince Istvan Báthory (1573). The gate was composed of an access tunnel above which it was located the guard room and the bridge lifting system. A watch tower was built near the gate. On the aisle connecting the West Gate with Bethlen Bast ion, there is located the Curtain between Ciunt Bastion and Bethlen Bastion. The curtain is a wall that connects the flanks between the two bastions. It is made of bricks and limestone from Betfia. The Bethlen Bastion was completed in 1618, accordings to inscriptions still visible on it.

It was designed and built under the direct supervision of the Italian architect Giacomo Resti from Verna. From the commemorative plaque with the inscription in Latin, we can learn the name and the coat of arms of the prince who ordered it, Gabriel Bethlen (Kovács, 1973; Kovács and Țoca, 1977). All this unit, including the inscription have been restored to the smallest detail. The curtain between Bethlen Bastion and Crăişorul Bastion was built between the years 1599-1604. The materials used for the construction of this wall were Betfia limestone, profiled stone originated from the old medieval constructions, brick, sandstone and schist. The Crăişorul Bastion was designed by the Italian architect Giulio Cesare Baldigara and built between 1569 and 1570, during the rule of the Prince Ioan Sigismund (Kovács, 1973; Kovács and Toca, 1977). The materials used to raise the bastion are about the same as in the other cases, river stones, tiles, bricks, schist and profiled stone from the old medieval buildings. In the same time the Red Bastion was built, somewhe re between 1584 and 1598, when the consolidation of the connecting passage between the two bastions, respectively at the courtain between the Crăişorul Bastion and the Red Bastion, also took place. Built at the order of the Prince István Báthory, the Red Bastion was constructed in different phases between 1580 and 1598. In the beginning, the Italian architect Domenico Ridolfini da Camerino, designed the bastion in a grand appearance, but eventually the work will be finished according to the more realistic plans of another Italian arch itect, Ottavio Baldigara (Kovács, 1973; Kovács and Ţoca, 1977). In 1660, during the Turkish siege, the eastern area the bastion was severely damaged by bombings over a length of more than 25 meters (Borcea, 1976). This section was rebuilt (the old angular architecture was improved) and reinforced (almost an extra meter was added to the wall thickness) in order to reduce the vulnerability during attacks.

The Courtain between the Golden Bastion and the Red Bastion was built approximately between 1582 and 1583, by the plans of the Italian architect Domenico Ridolfini da Camerino (Kovács, 1973; Kovács and Ţoca, 1977). In the initial phase the passage area, gates or other access routes. The East Gate of the fortress was built during the Habsburg domination (Emödi, 1998). The Golden Bastion, was built at the order of 
Prince István Báthory in 1572, according to the inscription on one of the stone slab from the entrance. The name comes from the golden coat of arms of the Báthory family. Due to its strategic importance and the vulnerable orientation towards the Ciuperca Hill, the Golden Bastion was severely damaged during the sieges of the Turkish armies (in 1598, 1658 and 1660). The Ciuperca Hill was the place where the Turkish armies lined up their artillery and bombed the fortress (Borcea, 1976). After the Turkish siege of 1660, both the Red and the Golden Bastion were almost completely destroyed, and the connecting courtain seriuosly damaged, therefore great renovations and consolidations were imposed. Massive reconstruction works took place on the northern side of the bastion, and also after the siege of the Austrian Army in 1692 (Emödi, 1998).

The Courtain between the Golden Bastion and the Ciunt Bastion was built between 1580 and 1581, at the order of Prince Christopher Bathory, in his final period of his reign. The basic structure and the courtain belt are made of massive blocks of stone. The brick from the construction was also visibly affected by the numerous armed confrontations. The most affected part was especially the upper section, being restored with limestone from Betfia. The Ciunt Bastion was built during the period of Prince István Báthory (1571 - 1575). A report of the Italian artillery commander from the Turkish siege of 1598 reveals that this construction was unfinished for a long time and for this reason it received the name Ciunt (single-horned). It is estimated that its completion took place between 1574 and 1580 , further in 1581 the Transylvanian Prince István Báthory makes direct reference to the three bastions built in the city of Oradea. Just a year after the siege of the fortress of 1598, in 1599, the upper part of the Bastion is restored, under the careful supervision of the Italian architect Cesare Porta, followed shortly by the architect Giovan-Marco Isolano (Kovács, 1973; Kovács and Ţoca, 1977). The year of restoration (1599) of the bastion is inscribed on the last stone block placed under the belt. In 1692 the fortress is subject to a new siege, where this time the northern side is badly damaged and destroyed. In the same time, the western flank remains almost untouched. During the Habsburg domination the northern flank will be fully restored and reinforced. Currently, the Ciunt Bastion hosts an outdoor Summer Teather. The Prince Palace from the A Building was constructed according to the plans of the Italian architect Giacomo Resti, between 1620 and 1629, in the time of Gábor Bethlen (Ţoca, 1973). This construction ends a historical and architectural period, being the termination of the medieval period and the beginning of the Renaissance period of the fortress. The Princely Palace became the first building erected in this fortified complex.

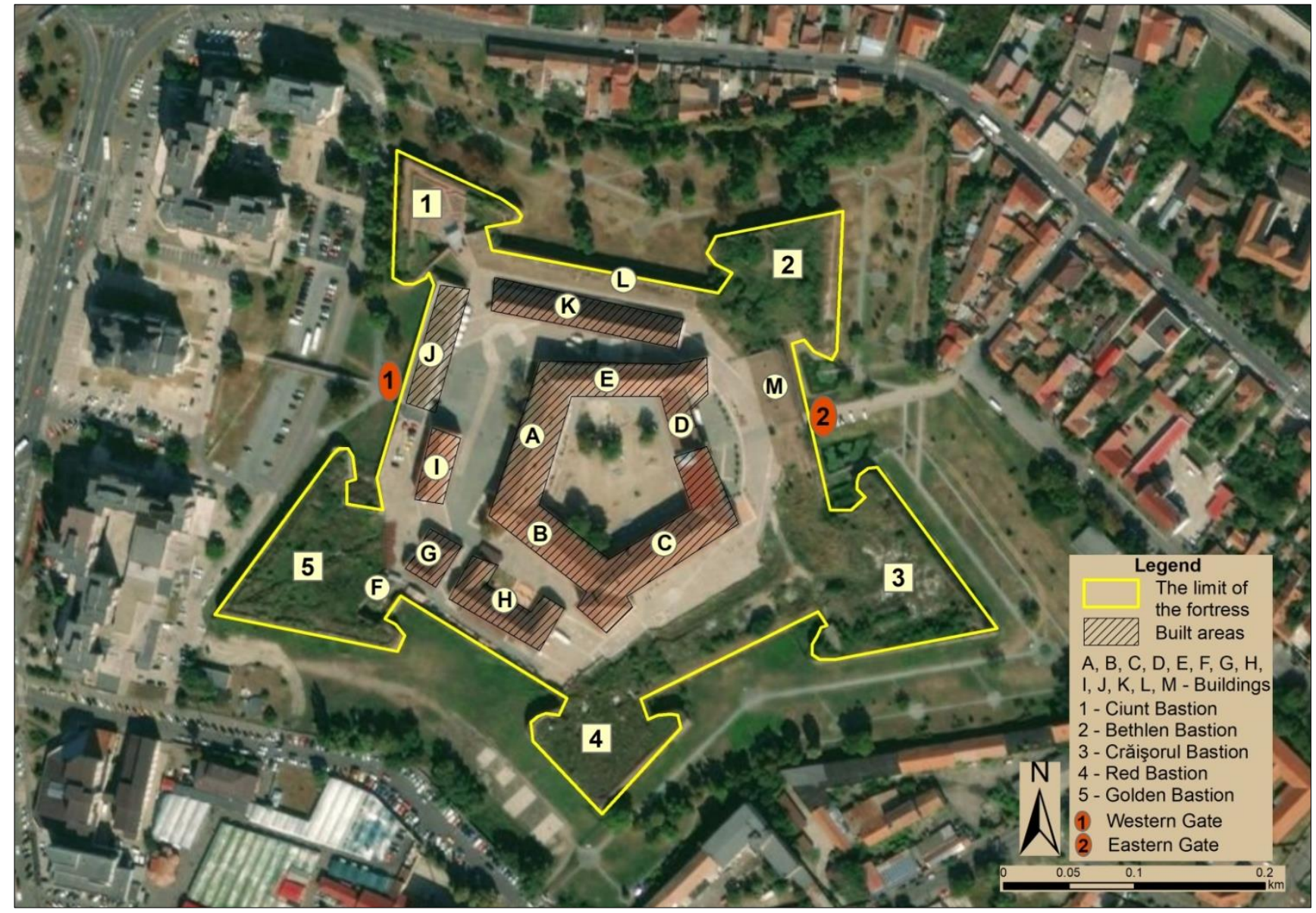

Figure 2. The buildings units composing the Fortress of Oradea (Romania)

(Data source: Ortophoto, National Romanian Agency for Cadastral Surveys and Real Estate Publicity)

This edifice retained its fortification role, even though it was used as a noble residency (the second residence after the one from Alba Iulia). Over time, the construction has been rehabilitated and resized with major architectural and strategic interventions. The evidence of the grandeur of this edifice is showed in the "Hall with Griffons" (Emödi, 1998; Emödi, 2007). The Prince Palace in B Building has about the same period of construction as the A Building of the Prince Palace. It was built in three stages, between 1620 and 1629, between 1638 - 1648, and between 1881 and 1882. Thus, the whole assembly takes on a barrack appearance, and establish the connection between, the Building A and the old Gothic Cathedral (Kovács and Ţoca, 1979; Emődi, 1998; Emődi, 2009). Following the current reconstruction works, a Lapidarium (a collection of large, carved or engraved stones, such as bas-reliefs, statues, funeral stones, etc.) was created in the basement of A building. The A \& B buildings host the Museum of the City of Oradea, containing a series of permanent exhibitions: "The history of Oradea photography", "Churches in the palace - archaeological research in the Prince Palace", "Exhibition of the Greek Catholic Episcopate of Oradea - History files", "Oradea Reformed Church Exhibition" and the "Exhibition of the Roman Catholic Episcopate of Oradea" (https://www.oradeaheritage.ro/cetatea-oradea/; https://muzeulmoo.ro/venue/expozitii-permanente/). The C Building is located on the south-east side of the Prince Palace, it was built between 
1638 and 1648 during the Prince György Rákóczi I, following the plans of the Transylvanian architect, Emeric Sardi from Cluj (Ţoca, 1973). It keeps the character of a prince residence, like the other two buildings, A and B. Between the eighteenth and nineteenth centuries this building will undergo several modifications and rehabilitation works ((Emödi, 1998; Emödi, 2009). Currently, the unit is an exhibition area, part of art galleries (https://www.oradeaheritage.ro/cetatea-oradea/). The Roman-Catholic Church from the Fortress was built between 1775 and 177 during the restoration of the fortress. It is constructed in Baroque style following the plans of the architect Lodovico Marini, associated with the period of Austrian domination (Kovács, 1973; Kovács and Ţoca, 1977). The tower of the church was destroyed by the fire of 1836, that devastated the city and it was rebuilt in a much simpler pyramidal form. Over time it served as a military garrison as a church for the French prisoners during the Napoleonic wars from 1793 to 1813. During the Communist period the church was used as a warehouse, and currently, after the renovation and rehabilitation of the fortress, the edifice serves as the Roman Catholic church for the ethnic Slovaks in Oradea.

The D Building was built in same construction period (between 1775 and 1777) by the same architect Lodovico Marini and used by the General Staff of the Austrian garrison in the fortress. This building was erected on the old site, in the immediate vicinity of the Eastern Gate, serving this access way in the fortress (Emödi, 1997; Emödi, 2009). The E Building comprises the northern side of the Prince Palace, having multiple functions in time. During the centuries it has been built, modified, extended and reconsolidated in several phases: the first phase between 1620 and 1629 (during the Prince Gábor Bethlen), the second phase was completed following the plans of the architect Giacomo Resti, the third phase between 1638 - 1648 (during the Prince György Rákóczy I), the final phase between 1775 - 1777 (accomplished following the complex restauration plans of the military architect Lodovico Marini). During the 18th century, this building hosted a barracks, but the darkest time of its use is were during the Communist period between 1945 and 1952, when it became a transit camp for the political prisoners of the time ((Emődi, 1997; Emődi, 2009). The G Building was built between 1775 and 1776, during the Habsburg domination (following the plans of the Italian architect Lodovico Marini). Having the shape of the letter U, the construction served as an annex of the palace, later as a food warehouse and in recent years it was used as an artistic creation workshop. In 1692, after the Austrian conquest of the fortress, at the order of the General Corbelli the Bakery of the H Building was built (composed of six bakeries and annexes) (Emődi, 1998; Emődi, 2007).

The architectural plan belonged to the military engineer, the Baron Ernst von Borgsdorf, the architect who also designed and supervised the rehabilitation and reconstruction works of the Oradea Fortress. This building has maintained its functional use for more than 300 years. Following the recent renovation works, this is the place where the visitors can experience and learn about traditional preparation of bread, as the unit hosts a Bread Museum (https://www.oradeaheritage.ro/cetatea-oradea/). The I building was built between 1692 and 1714 at the order of the captain of the fortress, and housed the military-administrative headquarters of the Austrian Army and the city's customs (Emödi, 1998; Emődi, 2007). It was realized between 1775-1777 during the period of Austrian domination, following the plans of the architect Lodovico Marini (Kovács, 1973; Kovács and Ţoca, 1977). The J Building was in the beginning (1573) the gate of the fortress, hosting also the gate tower and the clock tower, guarding the shed for carriages and stables on the right. Between 1775 and 1777, under the guidance of the architect Lodovico Marini, it was completely rebuilt, reaching the present form, where the two towers disappeared and the guard room was added (Kovács, 1973; Emődi, 1997; Emődi, 2007). The K Building was built between 1775 and 1777 over older constructions inhabited by the Pauline monks. Following the plans of the architect Lodovico Marini (Kovács, 1973; Kovács and Ţoca, 1977).

During the same period, there were built two bodies of building with the roles of official barrack and warehouse (in the initial phase a connecting passage made the connection to the building L). This unit had the role of offering accommodation to the officers (Emödi, 1998; Emődi, 2007). The unit hosts the Memorial "Resistance and Repression in Bihor", one of the few museum in Romania dedicated to the memory of former political prisoners who endured the horrors of the Communist Gulag (https://muzeulmoo.ro/memorialul-rezistentasi-represiune-in-bihor/). The northern Curtain is located in the L Building and it was built between 1775 and 1777, under the coordination and supervision of the military architect Lodovico Marini (Kovács, 1973). This building body had the role of casemate, being very spacious and very well consolidated (it was very exposed to attacks and sieges), having in certain periods a prison role as well. The M building is a group of buildings formed by the Eastern Gate and the two buildings attached to it, mainly the guard unit and stables.

The old curtain was built between 1582 and 1583, as an access passage between the Red and the Golden Bastion. Based on the vulnerability and its orientation toward the Ciuperca Hill, the eastern flank did not have access area or gate until 1777 . The gate was executed in 1777 (at the order of the fortress' command at that time) (Emödi, 2007; Emödi, 2009). On the left side of the gate a guard room was added and as a symmetry with the western gate, there were built buried stables and protected like a cazemate. The Summer Palace dates from about 1572, period when the Golden Bastion was built. From strategical reasons, two cazemates were built, connected by a passage route. Between 1638 and 1641 a recreation place (Summer House) was added (Emődi, 1998; Emődi, 2007).

\section{LOCAL PERSPECTIVES OVER THE FORTRESS}

\section{ANALYSIS OF THE GROUP OF RESPONDENTS}

Through a questionnaire survey the local perspectives of the fortress were highlighted. Analyzing the descriptive attributes of the survey sample it can be stated, that the gender ratio is balanced, $50 \%$ of respondents are men and $50 \%$ are women. In terms of age distribution groups, $60 \%$ of respondents are between 19 and 30 years old, $20 \%$ are between 30 and 45 years old, and 20\% are over 45 years old. From the point of view of education level, 10\% of the respondents graduated High School, $70 \%$ graduated BSc, and 20\% graduated MSc / PhD. Respectively, 50\% of the respondents are employed, and 50\% are Student / Pupils according to the professional status. In terms of monthly income, $40 \%$ of respondents had an income of less than EUR 400 per month, $30 \%$ had an income of between EUR 450 and EUR 900 per month and $20 \%$ had an income of more than EUR 900 per month (10\% of respondents did not answer this question). From the point of view of the areas of origin (within the Municipality of Oradea), $30 \%$ of the respondents came from Paleu, $20 \%$ came from the Nufărul neighborhood, and 10\% each came from the neighborhoods: Cantemir, Ioșia, Prima Universitatii, Rogerius and Velența (Figure 3).

\section{ANALYSIS OF ANSWERS}

For the analysis of the questionnaire answers, the weighted multiplication method was applied. Thus for each answer in the Strongly Disagree category the multiplication rate was 1 , for each answer in the Disagree category the multiplication rate was 2 , for each answer in the Undecided category the multiplication rate was 3 for each answer in Agree category, the multiplication rate was 4, and for each answer in the Strongly Agree category, the multiplication rate was 5 (for NA category, the multiplication rate was 0 ).

The maximum and minimum values were extracted from the obtained values. The difference obtained between the maximum and minimum values was divided by 3 resulting in the intervals: appreciated, average and unappreciated. To the question "The perception over the fortress. When you think at the fortress, do you think at which of the bellow elements?" (Figure 4), The answers of the respondents were in proportion of $4.5 \%$ from the Strongly Disagree category, $17.7 \%$ from the Disagree category, $13.8 \%$ from the Undecided category, $26.9 \%$ in the Agree category and 35.4\% in the Strongly Agree category (1.5\% of the questions were not answ ered). Following the application of the weighted multiplication method, from the answers to the question "The perception over the fortress. When 
you think at the fortress, do you think at which of the bellow elements?" the most popular were: Main gates of the fortress (4.5), Military history (4.3), Princely Palace (4.1) Roman Catholic Church (4.0) and Festivals, Ladislau days (4.0), and at the opposite pole were: Former Securitate memorial (2.8), Urban transformation during the socialism (3.1), The Curtains (3.1) and Gardens of the fortress (3.3).
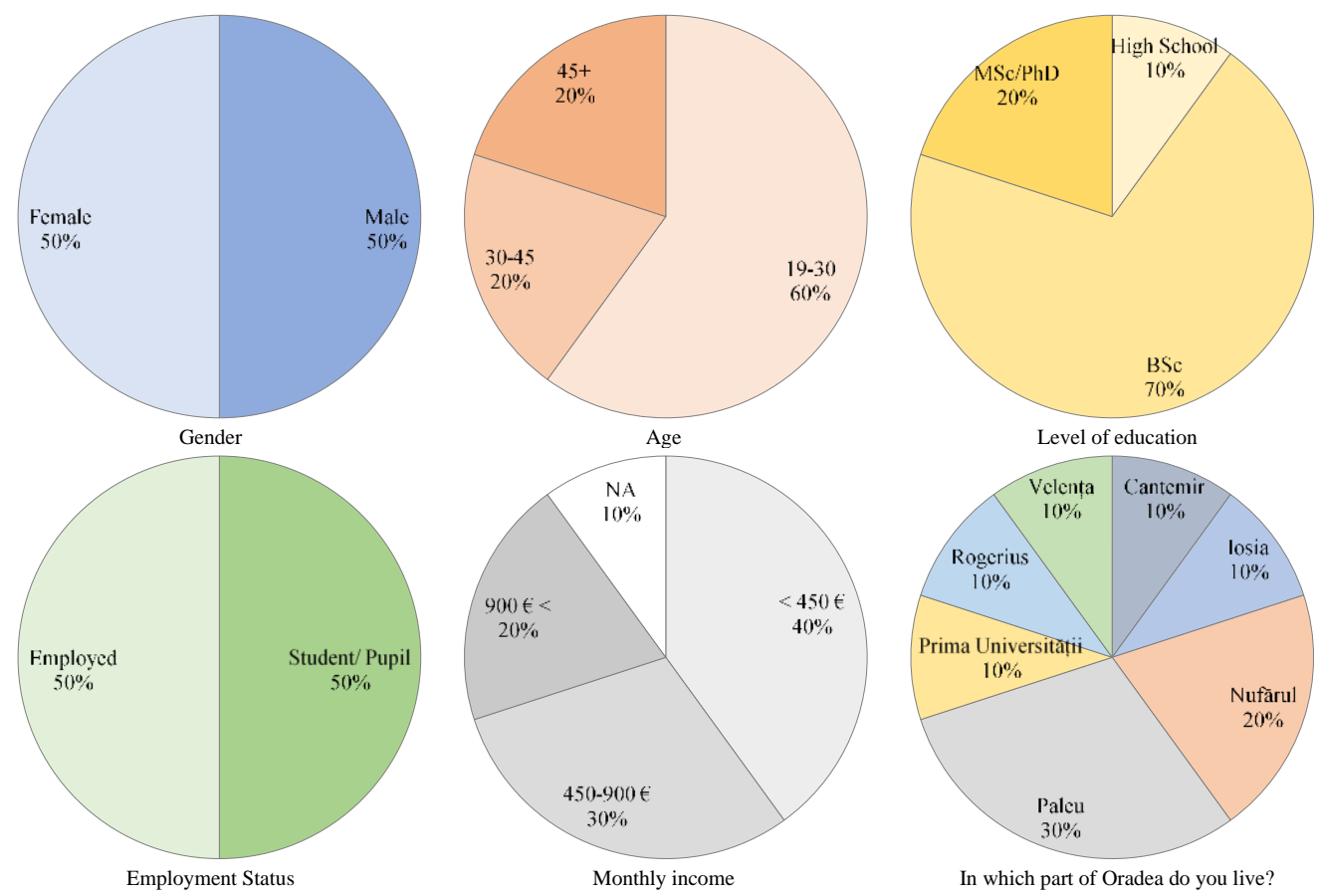

Figure 3. Characteristics of the group of respondents

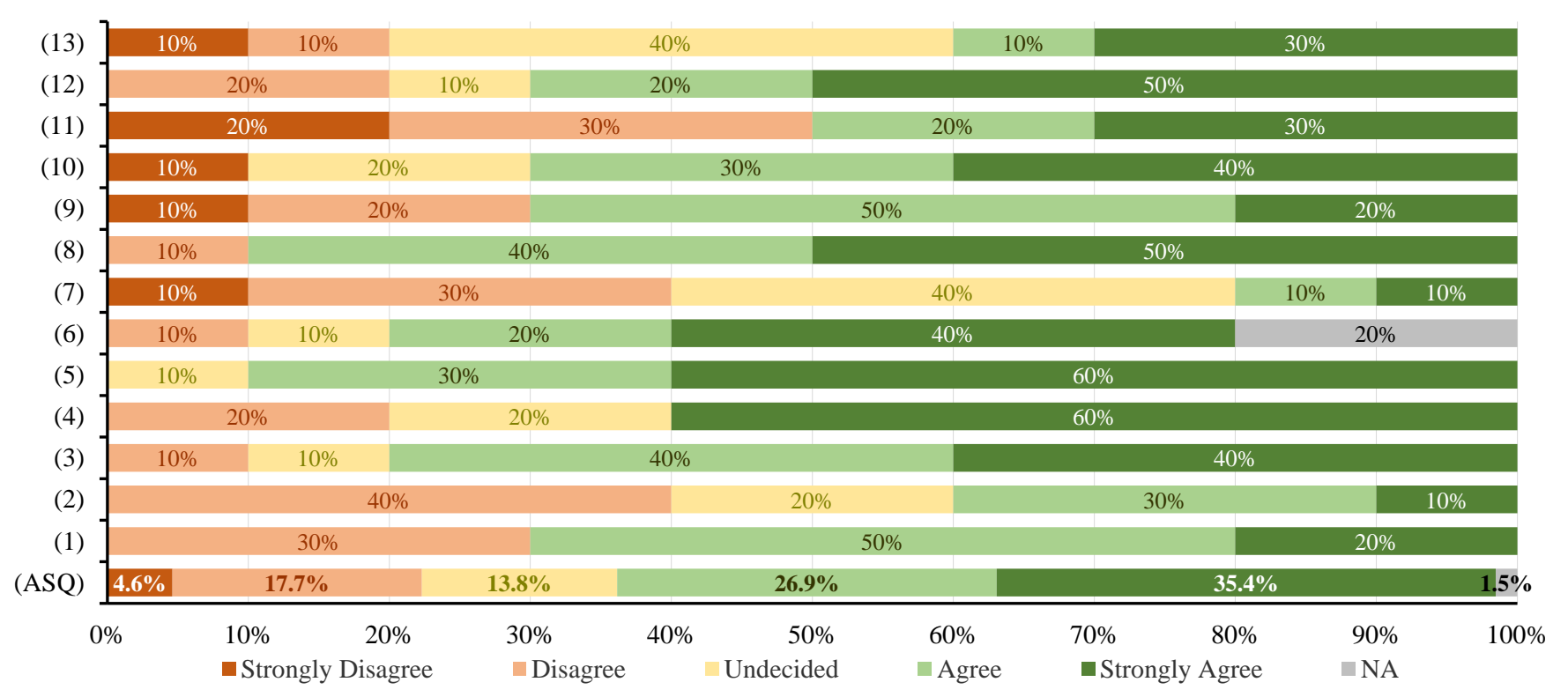

Figure 4. The perception over the fortress. When you think at the fortress, you think at which of the bellow elements?

Note (Figure 4): (1) - Renaissance bastions, (2) - The Curtains, (3) - Princely Palace, (4) - Roman Catholic Church, (5) - Main gates of the fortress, (6) - Gardens of the fortress, (7) - Former Securitate memorial, (8) - Military history, (9) - Transylvanian Princes, (10) - Multi ethnical connections, (11) - Urban transformation during the socialism, (12) - Festivals, Ladislau days, (13) - Religious meaning, (ASQ) - Average answers to questions.

To the questions related to the "The ambience of the Oradea Fortress, as an urban attraction venue" (Figure 5), the answers of the respondents were in proportion of $8.0 \%$ from the Strongly Disagree category, $16.7 \%$ from the Disagree category, $18.0 \%$ from the Undecided category, $36.7 \%$ in the Agree category and $20.0 \%$ in the Strongly Agree category ( $0.7 \%$ of the questions were not answered). Following the application of the weighted multiplication method, from the answers to the question "The ambience of the Oradea Fortress, as an urban attraction venue" the most appreciated were: You can get to Oradea fortress in less than 30 minutes, by using public transport (4.2), You can get to Oradea fortress in less than 1 hour, using any mean of transportation (4.1), The events held in the fortress attract tourists (4.1), The fortress is a safe place (4 . 0) and The fortress is an attractive tourist site in general (4.0), and at the opposite pole were located: When you visit the Oradea Fortress, you usually get to it by bicycle (2.3), When you visit the Oradea Fortress, you usually get to it by public transport (2.8), The fortress is well equipped with facilities for kids, benches, rest places, trash bins, etc. (2.8) and The fortress is well equipped for people with disabilities (2.8).

To the question "What are the reasons to visit the fortress?", The answers of the respondents were in proportion of 3.3\% from the Strongly Disagree category, $8.5 \%$ from the Disagree category, $27.0 \%$ from the Undecided category, $47.4 \%$ in the Agree category and $13.7 \%$ in the Strongly Agree category (no unanswered questions were recorded). 


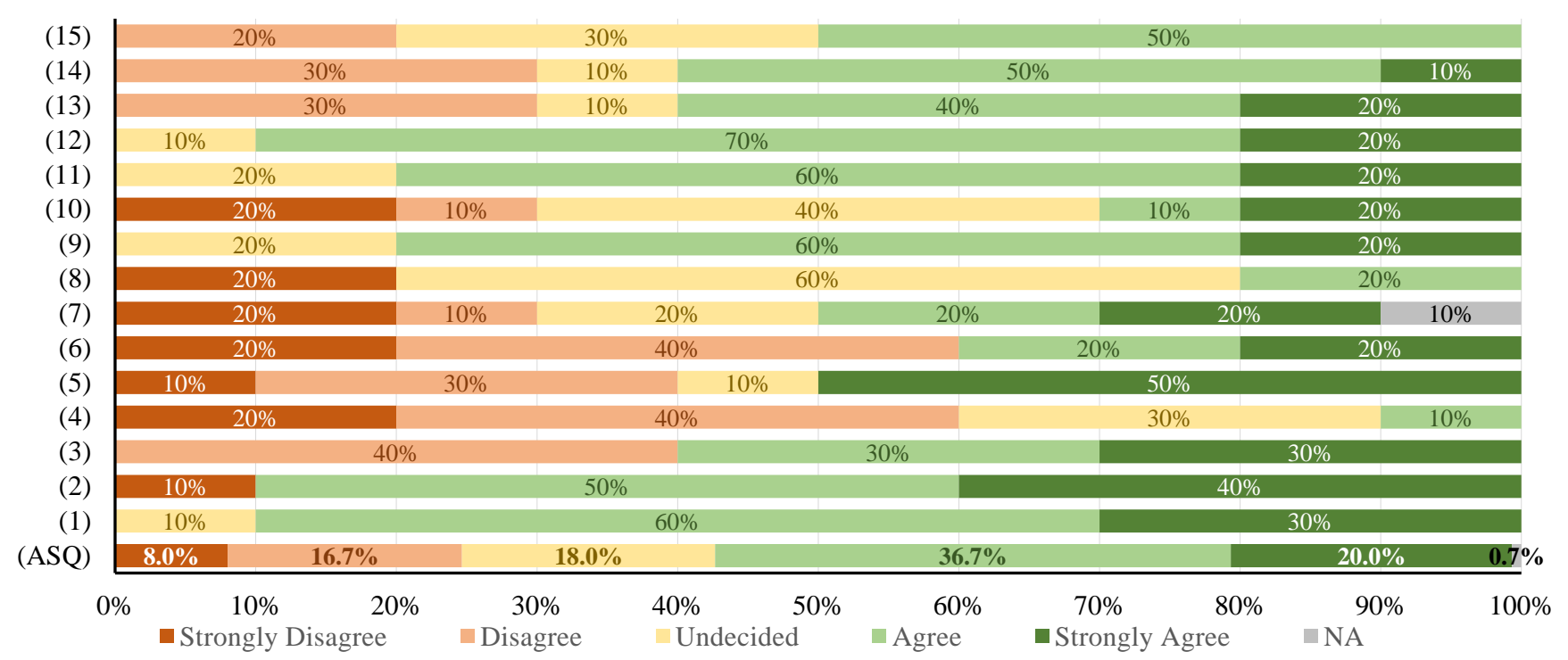

Figure 5. The ambience of the Oradea Fortress, as an urban attraction venue

Note (Figure 5): (1) - You can get to Oradea fortress in less than 30 minutes, by using the public transport, (2) - You can get to Oradea fortress in less than 1 hour, using any mean of transportation, (3) - When you visit the Oradea Fortress, you usually get to it by walking, (4) When you visit the Oradea Fortress, you usually get to it by bicycle, (5) - When you visit the Oradea Fortress, you usually get to it by car, (6) - When you visit the Oradea Fortress, you usually get to it by public transport, (7) - The fortress is well equipped with facilities for kids, benches, rest places, trash bins, etc., (8) - The fortress is well equipped for people with disabilities, (9) - The fortress is a safe place, (10) - The museums in the fortress are very interactive, (11) - The fortress is an attractive tourist site in general, (12) - The events held in the fortress attract tourists, (13) - The primary reason for visiting the fortress is the history, (14) - The primary reason for visiting the fortress is the architecture, (15) - The fortress has everything you need in order to have a better appreciation of its components, (ASQ) - Average answers to questions.

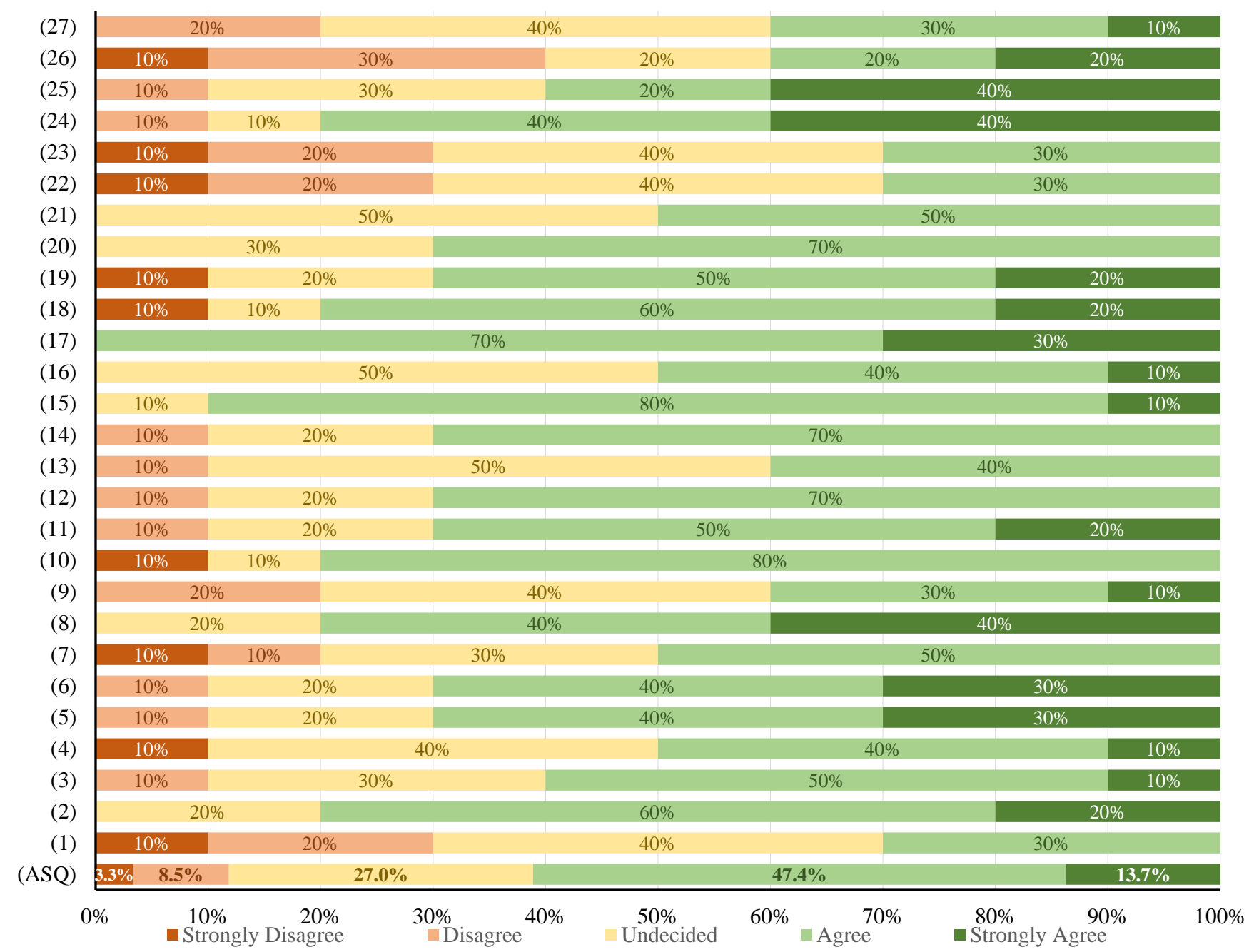

Figure 6. Evaluation of the answers from the questionnaires to the question "What are the reasons to visit the fortress?" 
Note (Figure 6): (1) - Prestige. I like to talk to everybody about my experiences at the fortress, (2) - Prestige. I like to take pictures of the fortress and events inside the fortress to show friends, (3) - Prestige. Experiences while visiting the fortress enriches me intellectually, (4) - Prestige. I want to give advice about the fortress and events in the fortress to people who want to travel, (5) - Prestige. I strongly promote Oradea fortress as one of the most interesting places Oradea has to offer, (6) - Prestige. I recommended Oradea fortress to a friend or colleague, (7) - Togetherness. Visiting the fortress enables me to meet new people with similar interests, (8) - Togetherness. Visiting the fortress enables me to have an enjoyable time with friends and/or family, (9) - Togetherness. Visiting the fortress increases friendship or kinship, (10) - Cultural experience. Visiting the fortress gives me an opportunity to increase my knowledge about different cultures, (11) Cultural experience. Visiting the fortress helps me see how local people lived, (12) - Cultural experience. Visiting the fortress makes me see the things that I don't normally see, (13) - Cultural experience. Visiting the fortress allows me discover something new, (14) - Cultural experience. Visiting the fortress is an authentic experience, (15) - Cultural experience. Visiting the fortress offers a unique opportunity to understand the local culture, (16) - Cultural experience. Visiting the fortress is a special experience, (17) - Escape from routine. Visiting the fortress helps me to relax, (18) - Escape from routine. Visiting the fortress takes me away from the crowds and noise, (19) - Escape from routine. Visiting the fortress makes me not worry about routine, (20) - Exciting experience. When visiting the fortress I have an expectation that it is exciting, (21) - Exciting experience. Visiting the fortress makes me excited, (22) - Exciting Experience. Visiting the fortress is thrilling to me, (23) - Exciting experience. Visiting the fortress makes me feel exhilarated, (24) - Entertainment. I visit the fortress especially for cultural festivals, (25) - Entertainment. I visit the fortress especially for concerts and music, (26) - Entertainment. I visit the fortress especially for children activities, (27) - Entertainment. I visit the fortress especially for art exhibitions, (ASQ) - Average answers to questions.

Following the application of the weighted multiplication method, from the answers to the question "What are the reasons to visit the fortress?" (Figure 6) the most appreciated were: The events held in the fortress attract tourists (4.5), The fortress is an attractive tourist site in general (4.3), Escape from routine. Visiting the fortress helps me to relax (4.3), Togetherness. Visiting the fortress enables me to have an enjoyable time with friends and / or family (4.2), The primary reason for visiting the fortress is the history (4.1), Entertainment. I visit the fortress especially for cultural festivals (4.1), Prestige. I like to take pictures of the fortress and events inside the fortress to show friends (4.0) and Cultural experience. Visiting the fortress offers a unique opportunity to understand the local culture (4.0), and at the opposite pole were located: Prestige. I like to talk to everybody about my experiences at the fortress (2.9), Exciting experience. Visiting the fortress is thrilling to me (2.9), Exciting experience. Visiting the fortress makes me feel exhilarated (2.9), Entertainment. I visit the fortress especially for children activities (3.1), Togetherness. Visiting the fortress enables me to meet new people with similar interests (3.2), Togetherness. Visiting the fortress increases friendship or kinship (3.3), Cultural experience. Visiting the fortress allows me to discover something new (3.3), Entertainment. I visit the fortress especially for art exhibitions (3.3) and Prestige. I want to give advice about the fortress and events in the fortress to people who want to travel (3.4).To the question "What do you value the most at the fortress?" (Figure 7), The answers of the respondents were in proportion of 5.5\% from the Strongly Disagree category, 3.6\% from the Disagree category, $13.6 \%$ from the Undecided category, $50.9 \%$ of the Agree category and $25.5 \%$ of the Strongly Agree category ( $0.9 \%$ of the questions were not answered). Following the application of the weighted multiplication method, from the answers to the question "What do you value the most at the fortress?" the most appreciated were: The historical value (4.4) and The tourist value (4.3), and at the opposite pole were: The value of social-economic utility (3.2).

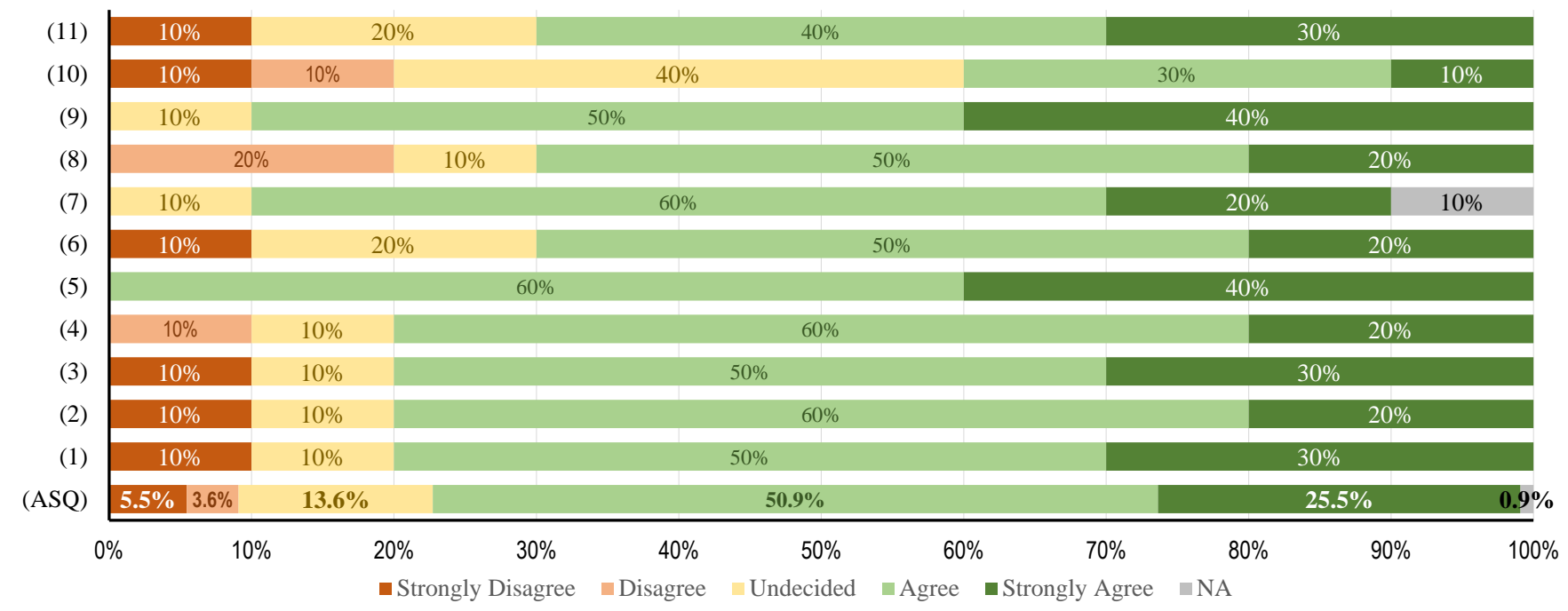

Figure 7. Evaluation of the answers from the questionnaires to the question "What do you value the most at the fortress?"

Note (Figure 7): (1) - The value of authenticity, (2) - The attractiveness values, (3) - The value of uniqueness, (4) - The artistic value, (5) The historic value, (6) - The diversity value, (7) - The educational value, (8) - The military value, (9) - The tourist value, (10) - The value of social-economic utility, (11) - The aesthetic value. (ASQ) - Average answers to questions.

\section{CONCLUSIONS}

The heritage sites provide important knowledge about the past, offering in the same time learning experiences, therefore connection particularly to formal education (based on the role of heritage, part of the curriculla, school field trips, site visits, university study programs) and informal education (unofficial learning during visits to historical sites, or ways sites are managed, informing public about negative historical events) (Timothy, 2011). The elements of the historical and cultural heritage represent an important asset of the cities, significantly influencing their economic and social development. Oradea Fortress is one of the most important late medieval architectural monuments in Transylvania and throughout the country. The fortress gradually lost its former function that of the outpost of Transylvania in the defensive system conceived and built by the Habsburg Empire and the Principality of Transylvania against the Ottoman Empire. During the 16th and 17th centuries, the Oradea Fortress was seen as a formidable bastion of Christian Europe in the face of Muslim expansion.

After a difficult period in the Communist era, when it functioned even as a transit camp for the opponents of the communist regime and then as a warehouse, today there is an extensive process of rehabilitation and restoration, within a European funding carried out by Oradea 
municipality who sees the fortress as a noteworthy potential for the sustainable development of tourism in the city. The survey shows that the values of the fortress are acknowledged, thus there is no significant gap between the physical-historical characteristics and their interpretation. The results of the questionnaire show that the historical significance and the authenticity are undoubtable of the Oradea Fortress according to the respondents. This confirms the identity generating function and justifies the dominating role in the urban texture.

The examined heritage is not only forming the aesthetics of the urban landscape of Oradea, but also gives clear possibility to its inhabitants and visitors, tourists to relax, to escape from the routine and to learn from the history in a multicultural setting. The venue also offers several touristic sights, cultural programs which partly commodifies the area, this may result some culure-related conflicts. Due to the multicultural character of the city and the architectural characteristics of the fortress, the site can be developed a significant destination. Beyond the obvious economic benefits, this development could contribute to the identity building of locals thus serving wider societal goals in accordance to the interrelation of space and society described in the Introduction part. As the results of our research show, the fortress is considered tangible and intangible heritage at the same time. The complex nature of this heritage requires comprehensive planning and implementation with horizontal and vertical partnerships, including several actors within the processes.

\section{REFERENCES}

Ashworth, G.J. (1991). Heritage planning: conservation as the management of urban change. Groningen. Geo Press. $150 \mathrm{p}$.

Ashworth, G.J., Graham, B., \& Tunbridge, J.E. (2007). Pluralising Pasts. Heritage, Identity and Place in Multicultural Societies. pp. 236, London, Pluto Press. Azhayev G., Esimova D., Sonko S.M., Safarov R., Shomanova Zh. \& Sambou A. (2020). Geoecological environmental evaluation of Pavlodar region of the Republic of Kazakhstan as a factor of perspectives for touristic activity. GeoJournal of Tourism and Geosites, 28(1), 104-113. https://doi.org/10.30892/gtg.28108-455

Badiali, F., \& Ilieș, D.C. (2011). La Fortezza Di Oradea (Romania) Nel 1598 Tra Cartografia e Cronaca. Fiamminghi e Italiani Descrivono la Città [The Fortress of Oradea (Romania) in 1598, Between Cartography and Chronicle. Flamings and Italians Describe the City. Bollettino dell'Associazione Italiana di Cartografia - supplemento, 143 (2011), Trieste, EUT Edizioni Università di Trieste,151-165.

Badiali, F., Ilieş, D.C., \& Castaldini, D. (2018). Tale of a City, Through its Urban Landscape and Cultural Heritage in the Heart of Europe: The Case Study of Oradea City (Romania). GeoJournal of Tourism and Geosites, 21(1), 88-102.

Balogh, J. (1982). Varadinum. Várad vár.a [Cetatea Oradea - monografie]. [Oradea Fortress - monograph], Budapesta, 1982. I-II.

Bar, R., Tătar, C.F., \& Herman, G.V. (2016). Satisfaction degree rating of tourist services in Buziaș spa, Timiş County, Romania. GeoJournal of Tourism and Geosites, 18(2), 212-223.

Bohland, J.D. \& Hague, E. (2009). Heritage and Identity. in Kitchin, R., Thrift, N. (eds.), Internationnnal Encyclopedia of Human Geography. Oxford, Elsevier, 109-114.

Biró, J. (1932). Nagyvárad barokk és neoklasszikus müvészeti emlékei, Budapesta [Baroque and neoclassical art monuments of Oradea, Budapest].

Borcea, L. (1976). Un document inedit despre căderea Oradei în mâna turcilor (scrisoarea din 31 august 1660) [An original document about the fall of Oradea into the hands of the Turks (letter of August 31, 1660)]. Crisia, VI, 1976.

Borcea, L., \& Gorun, G. (coord.) (2007). Istoria oraşului Oradea [History of the city of Oradea]. Ediţia a doua revăzută şi adăugită, [Second edition revised and added], Oradea, 2007.

Bowitz, E., \& Ibenholt, K. (2009). Economic impacts of cultural heritage -Research and Perspectives. Journal of Cultural Heritage, $20(1)$, 1-8.

Bryman, A. (2012). Social Research Methods. 4th edition, Oxford University Press, USA.

Chifor, A. (2011). Alegorii, Simboluri și Decorații în Arta Barocă Orădeana [Allegories, Symbols and Decorations in Oradean Baroque Art]. Oradea, Editura Muzeului Tării Crișurilor.

Chang, T.C., Milne, S., Fallon D., \& Pohlmann C. (1996). Urban heritage tourism: The global-local nexus, Annals of Tourism Research, 23(2), $284-305$.

Chelcea, S. (2007). Metodologia cercetării sociologice. Metode cantitative și calitative [Sociological research methodology. Quantitative and qualitative methods]. Editura Economică, București.

Corten, J.P., Geurts, E., Meurs, P., \& Vermeulen, R. (2014). Heritage as an Asset for Inner-city Development. Rotterdam, NAI010 Publishers.

Deac, L.A., Gozner, M., \& Sambou, A. (2019). Ethnographic museums in the rural areas of Crișana Region, Romania - Keepers of local heritage, tradition and lifestyle. GeoJournal of Tourism and Geosites, 27(4), 1251-1260. https://doi.org/10.30892/gtg.27411-430

Dejeu, P. (1926). Aşezămintele Culturale din Municipiul Oradea şi Judeţul Bihor [Cultural Settlements from Oradea Municipality and Bihor County]. Oradea, Editura Autorului, Tipografia Transilvania.

Dejeu, P. (1937). Instituţiunile culturale din Municipiul Oradea şi Judeţul Bihor [Cultural institutions from Oradea Municipality and Bihor County]. Oradea, Editura Autorului, Tipografia Franklin.

Dejeu, P. (1938). Vizita regală și programul edilitar [The royal visit and the municipal program]. Editura Autorului, Oradea, Tipografia Franklin.

Dezsi, S., Rusu, R., Ilies, M., Ilies, G., Badarau, A.S., \& Rosian, G. (2014). The role of rural tourism in the social and economic revitalisation of Lapus land (Maramures County, ROMANIA), in Geoconference on Ecology, Economics, Education and Legislation, Book Series: International Multidisciplinary Scientific GeoConference-SGEM- Proceedings Paper, II, 783-790. https://www.researchgate.net/publication/293110624

Dudaș, F. (1996). Românii din Oradea în Epoca Luminilor [Romanians from Oradea in the Age of Enlightenment]. I, Oradea.

Downs, R.M., \& Stea, D. (1973). Image and Environment. Chicago, IL: Aldine Publishing.

Emődi, I. (1998). Contribuţii la cunoaşterea istoriei construcției cetăţii renascentiste din Oradea [Contributions to the knowledge of the history of the construction of the Renaissance fortress from Oradea]. Date istorice din trecutul oraşului Oradea, [Historical data from the past of Oradea].

Emödi, T. (2007). Studiu de istoria artei privind corpurile A, G, H, I, K, L, M, P din incinta Cetăţii Oradea [Art history study regarding the bodies A, G, H, I, $K, L, M, P$ inside the Oradea Citadel]. Oradea.

Emődi, T. (2009). Studiu de istoria artei privind corpurile B, C, D, E din incinta Cetătii Oradea [Study of the history of art regarding the bodies B, C, D, E inside the Oradea Citadel]. Oradea.

Ennen, E. (2000). The Meaning of Heritage According to Connoisseurs, Rejecters and Take-it-or-leavers in Historic City Centres: two Dutch cities xperienced. International Journal of Heritage Studies. 6(4), 331-349.

Enyedi, G.Y., \& Kovács, Z. (2006). Social Sustainability of Historical City Centres in Central Europe - an Introduction. in Enyedi, GY., Kovács, Z. (eds.), Social Changes and Social Sustainability in Historical Urban Centres, Pécs, CRS HAS,11-19.

Firu, N. (1924). Oradea-Mare. Cultura Naţională, Bucuresti.

Forrest, R., \& Kearns, A. (2001). Social cohesion, social capital and the neighbourhood. Urban Studies, 38(12), $2125-2143$.

García-Hernández, M., De la Calle-Vaquero, M., \& Yubero, C. (2017). Cultural Heritage and Urban Tourism: Historic City Centres under Pressure. Sustainability 9(8):1346 doi:10.3390/su9081346

Gazdag, J., (1982). Fejezetek Bihar vármegye levéltárának feudális kori történetéhez, Debrecen [Chapters on the feudal history of the archives of Bihor County, Debrecen].

Gospodini, A. (2006). Portraying, classifying and understanding the emerging landscapes in the post-industrial city. Cities, 23(5), 311-330.

Gospodini, A (2004). Urban space morphology and place identity in european cities; built heritage and innovative design. Journal of Urban Design, 9 (2), 225-248.

Gozner, M., Tătar, C.F., Stupariu, M. \& Măduta, F.M. (2017). Nature, Photography and Tourism in Bihor-Vlădeasa Mountains (Romania). GeoJournal of Tourism and Geosites, 20(2), 210-219.

Hampton, K.N., Wellman, B. (2003). Neighboring in Netville: How the Internet Supports Community and Social Capital in a Wired Suburb. City and Community, 2(4). https://doi.org/10.1046/j.1535-6841.2003.00057.x

Harvey, D. (1989). The Condition of Postmodernity, Blackwell, Oxford.

Harvey, D. (2002). The art of rent: globalisation, monopoly and the commodification of culture, Socialist Register, 38.

Herman, G.V., Grama, V., Sonko, S.M., Boc E., Băican, D., Garai, L.D., Blaga, L., Josan, I., Caciora, T., Gruia K.A., Grecu, A., \& Peptenatu, D. (2020a). Online Information Premise in the Development of Bihor Tourist Destination, Romania. Folia Geographica, 62(1), $21-34$.

Herman G. V., Banto N., Caciora T., Ungureanu M., Furdui S., Grama V., Buhaș R., Buhas S. (2020b). Tourism in Bihor County, Romania. Trends and Prospects. Folia Geographica, 62(2), 87-105. 
Herman, G.V., Wendt, A.J., Dumbravă, R., \& Gozner, M. (2019). The role and importance of promotion centers in creating the image of tourist destination: Romania. Geographia Polonica, 92(4), 443-454. https://doi.org/10.7163/GPol.0158

Ilies, D.C., Buhas, R., Ilies, M., Ilies, A., Gaceu, O., Pop, A.C., Marcu, F., Buhas, S.D., Gozner, M., \& Baias, S. (2018). Sport Activities and Leisure in Nature 2000 Protected Area - Red Valley, Romania. Journal of Environmental Protection and Ecology, 19(1), 367-372.

Ilieș, A. (coord.), Baias, S., Baias, I., Blaga, L., Buhaș, S., Chiriac, A., Ciocan, J., Dăncuş, M., Deac A., Dragoș, P., Dumitrescu, G., Gaceu, O., Godea, I., Gozner, M., Grama, V., Herman, G., Hodor, N., Hurley, P., Ilieș, D.C., Ilieș, G., Ilieș, M., Josan, I., Leșe, G., Măduța, F., Mojolic, Diana, Morar, C., Olaru, M., Stașac, M., Stupariu, I.M., Sturza, A., Ștefănescu, B., Tătar, C., Vârnav, R., Vlaicu, M., \& Wendt, J. (2014). Crisana-Maramures. Atlas geografic al patrimoniului turistic. [Geographical atlas of tourism heritage], 302 p., (română/engleză), Editura Universității din Oradea, ISBN 978-606-10-1298-5.

Ilies, D. C., \& Josan, I. (2009). The tourist complex spa Băile Felix-Băile 1 mai-personality, distinctiveness by protection versus depersonalization and nonspecific by globalization. conceptual and practical aspects regarding the role of the natural and anthropic setting in tourist fitting. GeoJournal of Tourism and Geosites, 4(2), 179-185.

Ilieș, D.C., Ilieș, Al., Herman, G., Baias S., \& Morar, C. (2011). Geoturist map of the Băile Felix -Băile 1 Mai-Betfia Area (Bihor County, Romania). GeoJournal of Tourism and Geosites, 8(2), 219-226.

Ilieș D.C., Blaga L., Baias S., Morar C., \& Herman, G. (2010). Cross Border Natural Parks, Support for Regional Development. Case study of the Northern and Western Romanian Border. Revista română de geografie politică, 12(1), 126-139.

Ilieş, A., Ilieș, D. C., \& Deac, A. L. (2015). Selective, subjective or exclusive tourist map. GeoJournal of Tourism and Geosites, 16(2), $217-226$.

Ilieș, D.C., Caciora, T., Herman, G.V., Ilieș, A., Ropa, M., \& Baias, Ș. (2020). Geohazards affecting cultural heritage monuments. A complex case study from Romania. GeoJournal of Tourism and Geosites, 31(3), 1103-1112. https://doi.org/10.30892/gtg.31323-546

Kisic, V. (2016). Governing Heritage Dissonance. Belgrade, European Cultural Foundation.

Kovács, A. (2003). Kési reneszánsz építészet Erdélyben [Arhitectura renascentistă târzie în Transilvania]. [Late Renaissance architecture in Transylvania]. Budapest-Kolozsvár, 2003.

Kovács A., \& Țoca M. (1973). Arhitecți italieni în Transilvania în cursul secolelor al XVI-lea şi al XVII-lea. [Italian architects in Transylvania during the 16th and 17th centuries]. Studia Universitatis Babes-Bolyai SH. Cluj-Napoca, 18/1973.

Kovács, A., \& Ţoca, M. (1977). Contribuţii la cunoaşterea palatului în stil renascentist de la Oradea: Reliefurile în stuc din secolul al XVII-lea [Contributions to the knowledge of the Renaissance-style palace from Oradea: The stucco reliefs from the 17th century]. Biharea 4/1976. Oradea, 1977.

Kovács, A., \& Ţoca, M. (1979). Adalékok a váradi fejedelmi palota építéstörténetéhez. [Contribuţii la cunoaşterea palatului princiar de la Oradea]. [Contributions to the knowledge of the princely palace from Oradea]. Mővelidéstörténeti Tanulmányok. București, 1979.

Lakos, L. (1904). Nagy-Várad multja es jelenjéböl: A varosi levéltár adatai alapjan írta: Lakos Lajos [From the past and present of Nagy-Várad: Based on the data of the city archives by Lajos Lakos].

Lakos, M., \& Grundison, B.J. (1993). Conflict and Culture. pp.214. Research in Five Communities in Vancouver, British Columbia, UVic Institute for Dispute Resolution.

LeBaron, M. (2003). Culture and Conflict. Beyond Intractability. Guy Burgess and Heidi Burgess. Conflict Information Consortium, University of Colorado, Boulder.

Lečić, N., Mitković, P., \& Manić, B. (2017). Tourist valorisation of medieval fortresses along the Danube river: From the Serbian perspective. Facta universitatis - series, Architecture and Civil Engineering, 15(3), 465-475. https://doi.org/10.2298/FUACE170205036L

Lefebvre, H. (1991). The production of space. 454 p. Oxford, Basil Blackwell.

Li, Y. (2003). Heritage Tourism: The Contradictions between Conservation and Change. Tourism and Hospitality Research, 4(3), 247-261. https://doi.org/10.1177/146735840300400305

Lowenthal, D. (1998). The Purpose of Heritage. Lowenthal, The Heritage Crusade and the Spoils of History, Cambridge University Press,127-147.

Lugosi, P.D. Bell, D., \& Lugosi, K. (2010). Hospitality, culture and regeneration: Urban decay, entrepreneurship and the 'ruin' bars of Budapest. Urban Studies, 47 (14), 3079-3101.

Morar, C. (2012). Turism și dezvoltare regională durabilă în zonele miniere defavorizate ale județului Bihor [Tourism and Sustainable Regional Development in Bihor County's (Romania) Disadvantaged Mining Regions]. Universitatea din Oradea.

Morar, C., Nagy, Gy., Dulca, M., Boros, L., \& Sehida, K. (2019). Aspects Regarding the Military Cultural-Historical Heritage in the City of Oradea, Romania. Annals for Istrian and Mediterranean Studies, Series Historia et Sociologia 2. https://doi.org/10.19233/ASHS.2019.ŠT

Monyók, B., Kecskés, T. \& Kozma, G. (2020). The Relationship Between Heritage Products and Tourism in the Development Documents of Towns in HajdúBihar County. GeoJournal of Tourism and Geosites, 28(1), 257-267. https://doi.org/10.30892/gtg.28120-467.

Mugnano, S. \& P. Palvarini (2013). Sharing space without hanging together: a case study of social mix policy in Milan. Cities, 35 (1), $417-422$.

Niemets, L., Sehida, K., Kravchenko, K., Telebienieva, I., \& Peresadko, V. (2018). Trends Forming Policentric Model of Spatial Development and Implementation of the European Experience for Ukraine. Proceedings of the 32nd International Business Information Management Association Conference (IBIMA) (Seville, Spain, 15-16 November 2018). Editor Khalid S. Soliman. Seville, International Business Information Management Association (IBIMA), $362-374$.

Niemets, L., Suptelo, O., Lohvynova, M., Sehida, K., \& Telebienieva, I. (2019). Industrial Heritage as a Composition af Post-Industrial City (Basic Case Kharkov, Ukraine). Proceedings of the 33nd International Business Information Management Association Conference (IBIMA) (Granada, Spain, 10-11 April 2019). Editor Khalid S. Soliman. Granada, International Business Information Management Association (IBIMA).

Pap, Á. (2014). The Role of Built Cultural Heritage in Urban Development Strategies: Case Studies from Budapest. Journal of Settlements and Spatial Planning, 5(1),11-21.

Pașca, M. (2010a). Arhitecţii József şi László Vágó la Oradea. [Architects József and László Vágó in Oradea]. Oradea, Arca Publishing House.

Pașca, M. (2010b). Oradea around 1900. An Architectural Guide. Oradea, Arca Publishing House.

Rátz, T., Kundi, V., \& Michalkó, G. (2015). The Hidden Dimensions of Cultural Consumption within the Framework of Tourism Mobility. In: Sonnenburg, S; Wee, D (szerk.), Touring Consumption Wiesbaden, Németország, Springer VS, 285-302.

Ropa, L., \& Ropa, M. (2015). Aspecte Privind Schimbarea Toponimelor De Către Regimul Comunist Din România. [Aspects Regarding the Change of Toponyms by the Communist Regime in Romania]. Annals of Oradea University. Fasciola History-Archaeology, 26.

Ropa, M., \& Ropa, L. (2015). The Unemployment Evolution and Structure Depending on the Level of Education of the Graduated Educational Institution in the Period 2002-2011. Case Study: Depression of Beius. Revista Română de Geografie Politică, 19(2), 92-102.

Rusu, A.A. (2002). Cetatea Oradea. Monografie arheologică. Zona palatului episcopal [Oradea Fortress. Archaeological monograph.The area of the episcopal palace]. Oradea.

Scholtz, B. (1907). Nagy-Várad várának története [The history of the city of Oradea]. Oradea, 1907.

Sheperd, R. (2002). Commodification, culture and tourism. Tourist Studies, 2(2), 183-201.

Shomanova, Z.K., Safarov, R.Z., Tleulesov, A.K., Nosenko, Yu. G., Zhumakanova, A.S., Vladimir Viktorovich Larichkin, V.V. (2017). Study of composition of waste from metallurgy production aimed in use them as active phases of catalysts for hydrocarbon raw materials refining, News of the National Academy of Sciences of the Republic of Kazakhstan, Series of Geology and Technical Sciences, 2017, 6(426), 195-200

Scholtz, A., (1907). Geschichte der Festung Nagyvárad, Nagyvárad.

Soja, E.W. (1989). Postmodern Geographies: The Reassertion of Space in Critical Social Theory. London, 266 p., Verso Press.

Smith, M.K, Egedy, T., Csizmady, A., Jancsik, A., Olt, G., Michalkó, G. (2018). Non-planning and tourism consumption in Budapest's inner city. Tourism Geographies. International Journal of Tourism Space Place and Environment, 20(3), 524-548.

Suleimenov, I., Egemberdieva, Z., Bakirov, A., Baipakbayeva, S., Kopishev, E., Mun, G. (2020). Efficiency Problem of renewable energetics systems in the context of a «smart house» concept. E3S Web of Conferences, 164.

Valentine, G. (2013). Living with difference: proximity and encounter in urban life. Geography, 98(1), 4-9.

*** The World Cities Culture Report 2018, supported by Bloomberg Philanthropies.

*** The Implementation of the UNESCO (2018). Historic Urban Landscape Recommendation.

*** UNESCO (2003). Convention for the Safeguarding of Intangible Cultural Heritage.

*** UNESCO (2005). Convention on the Diversity of Cultural Expressions. 